\title{
Merkezi ve Yerel Yönetimlerin Gıda Güvenliğindeki Etkileri: Dünyadan ve Türkiye'den Örnekler
}

\author{
Effects of Central and Local Administrations on Food Safety: Examples from The World and From \\ Turkey
}

İlker ATíK

$\ddot{O} \breve{g r}$. Grv., Afyon Kocatepe Üniversitesi, Afyon MYO, Glda Teknolojisi Programl, ilkeratik@hotmail.com

https://orcid.org/ 0000-0001-8049-0465
Makale Başvuru Tarihi: 31.07.2019

Makale Kabul Tarihi: 29.09.2019

Makale Türü: Araştırma Makalesi

\section{Azize ATÍK}

Ögrr. Grv, Afyon Kocatepe Üniversitesi,

Sultandă̆ MYO, Gıda Teknolojisi Programı, azizeatik@gmail.com

https://orcid.org/ 0000-0002-3294-380X

Anahtar

Kelimeler:

Să̆llk,

Glda Güvenliği,

Merkezi Yönetim,

Yerel Yönetim,

Keywords:

Health,

Food safety,

Central

Administration,

Local Government,
Dünya'da her yıl milyonlarca kişi yedikleri ve içtikleri gıdalar yüzünden ya hastalanmaktadır ya da ölmektedir. Çünkü insanların yedikleri ve içtikleri gıdalar çeşitli sebeplerden dolayı bozulmakta ve bu bozulmuş ürünleri tüketmeleri sonucunda da insanlar gıda kaynakl hastallklara yakalanmaktadır. Gidaların bozulmasına fiziksel, kimyasal ve mikrobiyolojik etkenler sebep olmaktadır. Etkili bir kontrol mekanizması bu tehditleri minimum seviyeye indirmektedir. İste tam bu noktada ülkeler kendi vatandaşlarının sağlığını göz ö̈̈nünde bulundurarak kendi yönetim sistemlerine uyumlu olacak şekilde yasalar ve yönetmelikler çıkarmaktadır. Böylece etkin bir denetim mekanizması ile sağlıklı ve güvenilir gıdaya ulaşılmış olacaktır. Her ülke kendi imkanları doğrultusunda halk sağlığına önem vermektedir. Bu çalışmada hem Türkiye'den hem de dünyanın bazı ülkelerinden örnekler verilerek merkezi ve yerel yönetimler çerçevesinde gıda güvenliği konusu hakkında bilgi verilmeye çalışılmıştır.

\section{ABSTRACT}

Every year millions of people in the world get sick or die because of the food they eat and drink. Because the foods that people eat and drink are spoiled for various reasons and as a result of consuming these spoiled products, people get food-borne diseases. Physical, chemical and microbiological factors cause food spoilage. An effective control mechanism minimizes these threats. At this point, countries take into consideration the health of their citizens and adopt laws and regulations in line with their own management systems. Thus, healthy and reliable food will be achieved with an effective control mechanism. Every country attaches importance to public health in accordance with its own means. In this study; it has been tried to give information about food safety issues in the framework of the central and local governments by giving examples both from Turkey and some of the world's countries. 


\section{Gİiș}

Gıda tüketimi, canlılığın devamı için zorunlu bir eylemdir. Bu nedenle gıda üretimi ve tarımsal üretim insan sağlığı ile doğrudan ilgili olup; hukuk, çevre sağlığı, yönetim ve ekonomi gibi bilimler ile yakın ilişkilidir (Koç ve Uzmay, 2015:39). Gıda üretim ve tüketimine yönelik uygulanan gıda politikaları birçok disiplini aynı anda ilgilendiren yerel, bölgesel, ulusal ve küresel nitelikte çok yönlü ve bütüncül kamu hizmetlerini kapsamaktadır. $\mathrm{Bu}$ bağlamda gıda ürünlerinin üretimine yönelik ilk aşamasından başlayarak, tüketilmesine kadar geçen son sürecine kadar bir gıda güvencesi ve güvenliği içerisinde sürece tabi tutulmaktadır. Geliștirilen uluslararası standartlara bağlı olarak merkezi idareler tarafından her ülkede gida üretim ve tüketimi belirli ilke, standart, norm, usul ve esaslara tabi tutulmaktadır.

Gıda güvencesi, tüm insanların olağan ve sağlıklı yaşamları için gereksinim duydukları temel gıda ürünlerine temiz, sağlıklı, besleyici, sürekli, sürdürülebilir, kabul edilebilir ve yeterli bir şekilde mali ve fiziksel olarak erişebilmesi olarak ifade edilmektedir (FAO, 1983; CSFS, 2015; Koç ve Uzmay, 2015:39). Hiç şüphesiz bu durumun gerçekleşebilmesi, uluslararası standartların oluşturulması ile ülkelerin bu standartları hukuk normu olarak yürürlüğe koymaları il mümkündür. Mevcut uygulamaların yürürlükte olan mevzuat hükümlerine göre etkin ve düzenli olarak denetlenmesi gerekmektedir.

Gıda güvencesinin alt bileşenlerinden birisi gıda güvenliğidir. TGDF'ye (2011) göre gida güvenliği; kusursuz ve sağlıklı gıda üretiminin sağlanabilmesi için gıdaların üretim, işleme, muhafaza ve dağıtımları esnasında ihtiyaç duyulan kurallar ve alınması gereken önlemler bütünüdür. Gıda güvenliği ulusal nitelikte bir kamu hizmetidir. Birçok bilim dalını, sektörü, sosyal grubu ve paydaşı ilgilendirmektedir. Bu nedenle gıda güvenliğine yönelik politika, hizmet ve uygulamalar genel olarak merkezi idareler olan devletler tarafından hayata geçirilmektedir. Ancak yerel idareler, özel üretim bölge yöneticilikleri, üretim birlikleri, tüketici temsilcileri, gönüllü kuruluşlar ve diğer paydaşların da zaman zaman belirli oranlarda bu sürecin bir parçası olduğu görülmektedir. Başka bir deyişle yürürlüğe konulan hukuki normlar ile ilgili paydaşların gıda güvenliğinin sağlanması ile ilgili kontrol ve denetim mekanizmasına katkı sağlamaktadırlar. Örneğin Türkiye'de gıda işyerlerine "İ̧̧yeri Açma ve Çalışma Ruhsatı" verilmesi yerel yönetimlerin görev ve yetkisi kapsamındadır.

Mevzuat ve resmi kontroller, etkili gıda kontrolünün ve güvenli gıda üretiminin temel bileşenlerini temsil eder. Resmi gıda kontrolünün temeli, resmi faaliyetler ve bunları yürütenler için gerekli yetkiyi sağlayan gıda hukukunda yer almaktadır (Läikkö-Roto vd., 2016:172). Örneğin; Avrupa Birliği'nin tüm üye devletlerinin, resmi gıda kontrollerinin düzenli olarak, risk bazında ve uygun sıklıkta yapılmasını sağlamak için yasal bir zorunluluğu vardır. Bu durum, yetkili makamların iç veya dış denetimleri düzenlemesini de beraberinde getirir. Denetimler, yetkililerin kontrol planlarının yasama hedeflerine ulaşmak için uygun olup olmadığını, planların etkili bir şekilde uygulanıp uygulanmadığını ve kontrollerin ve ilgili sonuçların kontrol planlarına uygun olup olmadığını değerlendirir (Läikkö-Roto ve Nevas, 2014:135).

Halka açık alanlarda pazarlanan gıda ürünlerinin tüketicileri olarak insanların sağlığını ve çıkarlarını korumak hükümetlerin sorumluluğundadır. Bu durum, besleme, yetiştirme ve ana üretim, gıda işleme, depolama, nakliye ve perakende satış aşamalarını da içeren çiftlikten sofraya gıda zincirinin tüm özelliklerini dikkate alan etkin gıda kontrol sistemlerinin uygulanmasıyla sağlanabilir. Hükümetler, gıda üretim süreçlerinde yerine getirilmesi gereken asgari gıda güvenliğini veya pazarlama gereksinimlerini tanımlayan politikaların oluşturulmasını ve mevzuatın uygulanmasını içeren kararları alır. Ayrıca yine hükümetlerin, gıda işletmelerinin bu gereklilikleri eğitim, teftiş ve uygulama yoluyla takip etmelerini sağlamaları görevleri arasındadır. Her ülkenin kendi ulusal gıda denetimini uygulaması ve izleme programlarını oluşturması, hükümetlerin uygulanan kontrollerin gıda arzı güvenliğini sağlamak için gerçekten yeterli olup olmadığını doğrulamasını sağlar. Sonuç olarak, tüketicilerin sağlığının ve çıkarlarının gerçek anlamda korunmasını sağlamak için, hükümetlerin gıda güvenliği konularında ihtiyaç duyulan tüm bilgileri halka açıklaması yadsınamaz bir gerçektir (Kotsanopoulos ve Arvanitoyannis, 2017:763).

Yasama otoritesinin yanı sıra, kontrol otoritelerinin kontrolleri tamamlamak için yeterli ve uygun şekilde eğitilmiş personele ve ayrıca yeterli olanak ve donanıma ihtiyaçları vardır. Aksi takdirde kaynakların yetersiz olması ve kontrollerin uygulanmasına yönelik kapasite ve taahhüt eksikliğinin bulunması durumunda, herhangi bir kanunun etkinliğinin de zayıfladığı görülecektir (Läikkö-Roto ve Nevas, 2014:135).

Gıda güvenliği düzenlemelerinin etkin bir şekilde uygulanması, gıda güvenliğini sağlamak ve halk sağlığını korumak için esastır. Her ne kadar gıda tesislerinin teftiş sonuçları, doğrudan gıda kaynaklı salgınların meydana gelmesini kesin olarak tahmin etmek için kullanılamasa da veya diğer gıda güvenliği göstergeleri ile 
ilişkilendirilemese de (Leisner vd., 2014:76), bazı çalışmalar iyi işleyen bir resmi gıda kontrol sisteminin ve gıda güvenliği riskini önlemek için etkili kontrol eylemlerinin önemini vurgulamaktadır (Lundén, 2013:84).

Yaptırımlar için ayrıntılı düzenlemeler ve kurumsal çerçeveler ülkeler arasında farklılık göstermektedir. Ancak gıda işletmecileri ile gıda güvenliği mevzuatına uyumu sağlamayı amaçlayan ilkeler küreseldir. Resmi gıda kontrol eylemleri etkili ve tutarlı olmalı ve yaklaşım öncelikle danışma ve müzakere şeklinde olmalıdır. Bununla birlikte, şiddetli veya tekrarlayan gıda güvenliği ihlalleri durumunda, yetkililer daha katı kontrol eylemleri, yani uygulama (zorlayıc1) önlemler alarak uygunluk sağlamalıdır (Kettunen vd., 2018:199).

Hukuk kurallarının etkinliği, kontrol ve denetim mekanizmasının da etkin bir şekilde gerçekleşmesi ile mümkün olabilmektedir. Başka bir ifade ile etkin bir gıda denetimi mekanizması birbiri ile uyumlu hukuk normları ve denetim mekanizmalarının birlikteliği ile mümkündür. Bu nedenle gıda denetimi ile ilgili görev ve yetkilerin kamu kurum ve idareleri arasındaki paylaşımlı uyumlu, bütünsel ve koordineli olmalıdır. Birbirinden ayrı kamu tüzel kişiliğine sahip kurum ve idareler ortaya koyduğu uygulamalarda birbirini tamamlayıcı bir davranış sergilemelidir. Bu bağlamda hukuki anlamda bir yerel idare olan belediyelerin özerkliği, resmi gıda kontrolünün uygulanmasında farklı uygulamalara ve yaklaşımlara neden olmamalıdır. Yerel özerklik, bütünlükten kopma ve denetimde özverisizliğe yol açmamalıdır.

Avrupa Birliği'nde belirtilen birçok gıda güvenliği gereksinimi ve ulusal gıda güvenliği mevzuatı, duruma bağlı olarak yorumlanmasına izin vermektedir. $\mathrm{Bu}$ nedenle, benzer durumlar farklı düzenleme sonuçlarına neden olabilmektedir. Daha önce yapılan çalışmalarda; Avrupa Birliği üyesi farklı ülkelerde uygulama önlemlerinin kullanımının birimler arasında değiştiği gösterilmiş ve birimler ile teftiş memurları arasındaki diğer kontrol prosedürleri ve denetim uygulamalarında da tutarsızlık olduğu bildirilmiştir. Hatta aynı ülkede yer alan farklı belediyelerde dahi uygulamada farkl1lıkların görüldüğü belirtilmiştir (Kettunen vd., 2017:35).

AB mevzuatı, gıda kontrolünün kalite güvence programlarının sonuçlarını dikkate alması gerektiğini belirtmektedir. Bazı ülkeler gıda güvenliği yönetim sistemlerini kullanma ve gıda kontrolündeki denetimleri kullanma olasılığını da dahil etmiştir. Belçika, Danimarka, İngiltere ve Hollanda gibi AB ülkelerinde, resmi teftişlerin sıklığı onaylı bir gıda güvenliği yönetim sistemlerine sahip gıda işletmelerinde belirli şartlara göre azaltılabilmektedir. Bunun yanında, Kanada bu olasılığı içeren bir politika beyanı ilan etmiştir. ABD'de ise gıda güvenliği yönetim sistemlerinin önemi çok fazladır. Çünkü bu sistemler merkezi ve yerel yönetimleri takiben özel sektörün de gıda işletmelerinde yapılan denetimlerinde etkin bir rol üstlenmesini sağlamıştır (Turku vd., 2018:459).

\section{MERKEZI VE YEREL YÖNETIMLER AÇISINDAN GIDA GÜVENLIĞİININ SAĞLANMASI KONUSUNDA FARLI ÜLKELERDEN ÖRNEKLER}

İnsanoğlunun en temel ihtiyaçlarından birisi beslenmedir. Dolayısıyla günlük olarak tüketilen yiyecek ve içeceklerin kaynağı, ne şekilde hazırlandığı ve müşteriye nasıl sunulduğu büyük önem taşımaktadır. Güvenli gıda kavramı dünya üzerinde yaşayan bütün insanları ilgilendiren ve gerekli yasal düzenlemeler ile sınırlarının belirlenmesi gereken bir kavramdır. Bu yüzden bütün ülkeler kendi mevzuatları doğrultusunda vatandaşlarına güvenli gıdayı ulaştırma çabası içerisindedirler. Hangi ülke olursa olsun hem merkezi yönetimi hem de yerel yönetimleri çeşitli yasalar ve yönetmelikler ile ülke genelinde, bölgelerde ve yerel idari yerleşim birimlerinde gıdaların güvenliğini sağlamaya çalışmaktadırlar. Bu bölümde Dünya'nın farklı bölgelerinde yer alan hem gelişmiş hem de gelişmekte olan bazı ülkelerde gıda güvenliği konusunda ne gibi çalışmaların yürütüldügü anlatılmaya çalışılmıştır.

\subsection{Avusturya}

Avusturya'da, resmi gıda kontrol prensipleri, Gıda Güvenliği ve Tüketicinin Korunması Yasası ve bunun sonucunda yayınlanan düzenlemeler tarafından yönetilir. Bu belgelere dayanarak, Avusturya Federal Çalışma, Sosyal İşler, Sağlık ve Tüketicinin Korunması Bakanlığı tarafından yıllık bir Ulusal Kontrol Planı hazırlanmaktadır. Bu plan birkaç yönü kapsar; yıllık örnekleme planı gıda kategorisine göre alınacak örnek sayısını belirtir ve denetim planı ise denetlenecek gıda işletmecisi sayısını (Gís) belirler. Genel Gıda Kanunu'na göre, gıda güvenliğinin sağlanmasında birincil yasal sorumluluk GíS'e aittir. Resmi gıda kontrolörünün görevi, yasal gereklilikleri GiS'in kendi kendini denetleme sistemi tarafından yerine getirilip getirilmediğini izlemek ve doğrulamaktır. HACCP (tehlike analizi ve kritik kontrol noktaları) sistemlerinin değerlendirilmesinin yanı sıra, resmi denetimler hijyen denetimlerine odaklanmaktadır. Bu denetimlerin sıklığı, risk değerlendirmeleri üzerine 
kuruludur. Et işletmeleri (et işleme ve işleme işletmeleri, et tedarik işletmeleri) ile ilgili yüksek risk nedeniyle, bu sektör ayrı bir denetim planı kapsamındadır. Gıda örnekleri tüm gıda zinciri boyunca alınır ve planlı örnekleri ve şüpheli örnekleri içerir. Planlanan numuneler, hem üretim hem de perakende düzeyinde, yıllık örnekleme planına göre tüm yıl boyunca rutin olarak alınır. Numune sayısı, önceki yıllardaki denetimlerin sonuçlarına ve Avusturyalı uzmanlar tarafindan gerçekleştirilen bir risk sınıflandırmasına dayanarak hesaplanmaktadır. Belirli gıdalarla ilgili soruları etkin bir şekilde cevaplamak için yıllık olarak ek kampanyalar başlatılmaktadır (örneğin, fındıktaki mikotoksinlerin değerlendirilmesi veya perakende olarak taze balıkların mikrobiyolojisi). Planlanan örneklemenin yanı sıra, tüketici şikayetleri, denetleyici kurumların algıları, Gıda ve Yem İçin Hızlı Uyarı Sistemi (RASFF) veya Avrupa Birliği'nin Hızlı Bilgi Değişimi Sisteminin (RAPEX) Hızlı Uyarı Sistemindeki raporları sonrasında şüpheli durumlar için örnekleme yapılır. Denetimlerin ve örneklemenin sonuçları yıllık Gıda Güvenliği Raporunda sunulur. Bu yıllık raporlar, tek bir yılın sonuçlarına kapsamlı bir genel bakış sunar. Bu kapsamda bakıldığında Avusturya'da merkezi yönetimin gıda güvenliği konusunda tek sorumlu otorite olduğu söylenebilir. 2017 yılından bu yana, çalışmaların sonuçları Avusturya Sağlık ve Gıda Güvenliği Ajansı tarafından yayınlanmaktadır (Lueckl vd., 2019:190-191).

Avusturya'nın; Avrupa Birliği’nin gerektirdiği yasal zorunluluklar doğrultusunda, gıda güvenliği konusundaki hassasiyeti bir hayli fazladır. Burada sıkı denetim prensipleri uygulanmaktadır. Farklı zamanlarda çeşitli çalışmalarla gıda güvenliği ve gıda denetimi konusundaki aksaklıklar ve eksiklikler tespit edilerek en kısa zamanda düzeltilme yoluna gidilmektedir (Gabernig vd., 2016:165-166).

\section{2. Çin}

Çin'de, gıda kontrol sistemlerinin kurulması ile ilgili iş ve işlemler sadece merkezi yönetim tarafindan yürütülmektedir. Ancak bu durum gıda kontrol sistemlerinin işleyişinde aşırı derecede eksik uygulamalara sebep olmaktadır. Bu nedenle, gıda kontrol sistemlerinin kurulması kaçınılmaz olarak uzun vadeli bir süreç haline gelmektedir. Tarımsal gıda tüketimi, Çin'deki toplam gıda tüketiminin \% 70'inden fazlasını oluştururken, yüksek oranda işlenmiş gıda tüketimi \% 30'dan azdır. Son 10 yılda, Çin'deki yaklaşık 50 gıda güvenliği olayının 30'dan fazlasının tarımsal gıda güvenliği olaylarından oluştuğu belirtilmiştir. Bu nedenle, insanlar tarımsal gıda güvenliği konularında büyük endişe duymaktadırlar. Halen, bir dizi tarımsal gıda korkusu (dioksin, melamin ve malaşit yeşili) Çin halkının tarımsal gıda güvenliğine olan güvenini ciddi şekilde baltalamıştır. Ek olarak, bu durum Çin'in gıda ihracatında da düşüş görülmesi gibi olumsuzluklara sebep olmuştur. Zararı azaltmak için Çin hükümeti tarımsal gıda kontrolünü sıkılaştırmak için çok sayıda önlem almıştır (Yang vd., 2012:223).

Bazı kaynaklara göre; gıda ürünlerinde tağşişin sadece ekonomik kayıplara neden olduğu belirtilirken tüketici sağlığı üzerinde bu durumun çok fazla olumsuz etkisinin bulunmadığ bildirilmektedir. Bu söylem hala geçerliliğini koruyan bir tartışma konusu olsa da, 2008 yılında Çin'deki melamin ilaveli bebek maması krizi, gıda kaçakçılığının ciddi bir gıda güvenliği ve halk sağlığı sorunu olabileceğini açıkça göstermektedir. Çin Halk Cumhuriyeti Sağlık Bakanlığı tarafından hazırlanan rapora göre; Kasım 2008 sonuna kadar, Çin'deki 294.000 bebek ve küçük çocuğa idrar yolu taşı teşhisi konmuştu. Hastaların çoğunda semptom ve belirti olmamasına rağmen, bazı hastalarda akut böbrek yetmezliği meydana gelmişti. 50.000'den fazla bebek, ölüm vakalarının görülmeye başlanması ile birlikte hastaneye kaldırılmıştı. Bu gıda güvenliği krizi sadece halk sağlığının ciddi bir sorunu değil, aynı zamanda uluslararası ekonomi, gıda ticareti ve hatta politika üzerinde de ciddi bir etkiye sahipti. Sonuç olarak, hangi marka olursa olsun Çin'den gelen bebek mamaları birçok ülke tarafından ithalattan reddedilmişti. Bu durum bir çok açıdan Çin'i sıkıntıya sokmuştu. Durum böyle olunca Çin Halk Cumhuriyeti gibi Dünya'nın en kalabalık ülkesinde gıda güvenliği konusu ülkenin en önemli gündem maddelerinden biri olmuştur (Chen, 2009:109).

Çin'de halk hükümetleri (people's governments); merkez, il, belediye, ilçe ve kasaba düzeyinde kuruludur. Tarımsal gıda kontrolü, esas olarak, ilçe düzeyinde ya da daha üstündeki halk hükümetleri altında yer alan tarımla ilgili idari bölümler tarafından gerçekleştirilmektedir. Tarımsal idari bölümlerin tarımsal gıda kontrol çalışmaları halk hükümetleri tarafından düzenlenir, ancak bu yerel yönetimler tarımsal idari bölümlerden daha yüksek veya merkezi düzeylerde bazı teknik veya metodolojik rehberlik alabilir. 2006 yılında, Çin Halk Cumhuriyeti Tarım Ürünlerinin Kalite ve Güvenliği Kanunu; hükümetlerin, tarım ürünlerinin kalite ve güvenlik kontrolü, tarımsal ürün operatörlerinin faaliyetleri ve denetleme bölümlerinin gereklilikleri konusundaki sorumluluklarını düzenlemişsir. Aynı yıl Tarım Bakanlığı, hayvancılık ve kümes hayvanlarının etiketlenmesi ile ilgili 67/2006 sayılı tüzük ve 1slah kayıt dosyaları, tarımsal ürünlerin ambalajlanması ve etiketlenmesi ile ilgili 70/2006 sayılı yönetmelik ve üretim yeri ile ilgili 71/2006 sayılı yönetmelik uyarınca tarımsal ürünlerin listesi dahil üç yönüyle birlikte Çin Halk Cumhuriyeti Tarımsal Ürünlerin Kalite ve Güvenliği Kanununa göre bazı 
özel şartları zorunlu kılmıştır. 2009 yılında Çin Halk Cumhuriyeti Gıda Güvenliği Kanunu; üçüncü bölümde tarımsal gıda için kalite ve güvenlik standartlarının oluşturulmasını ve yedinci bölümde, tarımsal gıda ile ilgili güvenlik bilgilerinin yayınlanmasını düzenlemiştir (Yang vd., 2012:224).

\subsection{Finlandiya}

Finlandiya'da gıda güvenliği konusunda hem merkezi hükümet hem de belediyeler gıda güvenliği konusunda sorumludurlar. Birbirleri ile işbirliği içerisinde çalışmakla birlikte denetim yaptı̆̆ 1 ve kontrol ettiği alanlar farklıdır. Finlandiya'da; ulusal düzeyde kontrol edilen mezbahalardan merkezi hükümet sorumlu iken bunun dışındaki gıda işletmelerinden belediye gıda kontrol yetkilileri sorumludur. Finlandiya Gıda Güvenliği Otoritesi Evira, gıda kontrol düzenlemelerinin ulusal rehberliğinden sorumludur ve gida işletmelerinde yeterli hijyen koşulları, kendi kendine kontrol sistemleri ve HACCP prosedürleri ile ilgili birkaç kılavuz sağlamıştır. Evira ayrıca, zorlayıcı önlemler de dahil olmak üzere resmi gıda kontrolündeki eylemler için kılavuzlar yayınlamıştır. Yönergelere rağmen, Avrupa Komisyonu'nun Gıda ve Veterinerlik Bürosu (FVO) son zamanlarda resmi kontrollerde bazı eksiklikleri gözlemlemiştir. $\mathrm{Bu}$ eksiklikler örneğin; gıda işletmelerinin HACCP prosedürlerinin değerlendirilmesi ve tespit edilen uyumsuzlukların düzeltilmesi için yeterli önlemlerin alınması ile ilgilidir. Yakın tarihli bir araştırma, Finlandiya'da, özellikle kullanımları için yeterli gerekçesi olduğu durumlarda zorlayıcı önlemlerin seçildiği sonucuna varmıştır (Läikkö-Roto vd., 2015:341).

Finlandiya'da halka açık hazır yemek sistemlerinin, ülkede gün içerisinde insanların tüketmiş olduğu yemeklerde hayati bir rol oynadığ 1 belirtilmektedir. Ülke nüfusunun yaklaşık üçte biri günlük yemek servisi kullanmaktadır. İnsanlar, gündüz bakım merkezlerinde, okullarda ve iş yerlerinde ve hastaneler, ordu, hapishaneler ve bakımevlerinde gibi kurumlarda yemek yemektedirler. Okullarda ve işyerlerinde servis edilen yemekler, sağliklı beslenme ve uygun yemekler hakkındaki fikirlerin temelini oluşturan modellerdir. Bunun güçlü bir örneği, taze sebzeleri sıcak yemeklere dahil etme uygulamasıdır. Dolayısıyla toplu tüketimin bir hayli fazla olduğu bu ülkede de gida güvenliği konusunda denetimler son derece önemlidir (Mäkelä ve Rautavirta, 2018:132).

Denetimler sırasında gıda kontrol görevlileri tarafından verilen talimatların ve yüksek kaliteli rehberliğin, gıda işletmelerinde gıda güvenliği üzerinde büyük bir etkisi olduğu öne sürülmüştür. Finlandiya Gıda Yasası, yetkili makamların yasalara uymasını talep etmekle birlikte, gerektiğinde gıda işletmecilerine tavsiye ve talimatlar vermelerini şart koşar. Yetkililer aynı zamanda kontrol nesnelerine eşit davranırlar. Ayrıca bu kişilerin tüm eylem ve önlemlerinin takip edilen amaç için tarafsız ve orantılı olması gerekmektedir. Resmi kontrollerde tutarlı olmak son derece önemlidir. Aksi bir durumda, aynı işi yapan farklı gıda işletmelerinde gerçekleştirilen kontrollerde eşit olmayan maliyet yükleri ortaya çıkabilir. Farklı gereksinimler aynı zamanda işletmelerdeki operasyonların planlanmasını zorlaştırabilir. Ayrıca, kontrol sonuçlarının açık bir şekilde yayınlanması için kontrollerin tutarlılığı esastır (Läikkö-Roto vd., 2015:342).

\subsection{Hindistan}

Hindistan'da gıda güvenliği konusunda yetkili makam merkezi yönetimdir. Merkezi yönetimin geliştirmiş olduğu Hint Ulusal Gıda Kontrol Sistemi'nde yer alanlar; sistemin değerlendirilmesi ve tasarlanması için uğraşan düzenleyiciler; bakanlıklarda görev alanlar, laboratuvarlarda çalışanlar ve gıda işletmecileridir. Sistemin hazırlanması, yürütülmesi ve gerekli görüldüğü yerlerde revize edilmesi için uzman kişilerin görüşüne büyük önem verilmektedir. Öncelikle ulusal gıda kontrol sisteminin; ithalat, ihracat ve yerel olmak üzere üç yönü bulunmaktadır. Hindistan'da, yerel ve ithal gıda ticareti, Gıda Güvenliği Standartları Kanunu (2008) kapsamında, ihraç gıda ticareti ise öncelikle İhracat (Kalite Kontrol ve Muayene) Kanunu (1963) kapsamındadır (Shukla vd., 2018:121).

Çin Halk Cumhuriyeti’nde bebek mamalarında görülen melamin sıkıntısı gibi dünyanın ikinci kalabalık ülkesi olan Hindistan'da bir sürü çocuk festival sezonunda Kuttu ununun tağşişi yüzünden kontamine olmuş öğle yemeklerini yedikten sonra hastalanmıştır. $\mathrm{Bu}$ tarz gıda kaynaklı hastalıklar ticarete ve turizme zarar verebilmekte ve kazanç kaybı, işsizliğin artması ve tazminat davası gibi istenmeyen sonuçlara neden olabilmektedir. Bu durumların önüne geçebilmek için; Dünya Ticaret Örgütü (DTÖ) uyarınca; Ticarette Teknik Engel (TTE) anlaşması tüm ülkelerin uluslararası piyasada ticaret yapması için eşit firsat vermektedir. Aynı zamanda, Gıda Standartları Komisyonu tarafindan belirlenen gida standartları tüm üyelerin eşit şartlarda rekabet etmesini sağlamaktadır. Ticaret engellerinin ortadan kalkması ihracatçı ülkelerin asgari gereklilikleri yerine getirmesi ile mümkündür. Güvenli gıda sağlama sorumluluğu anlaşmaya imza atan ülkeye aittir (Shukla vd., 
2014:401).

Hindistan'da, Gıda Güvenliği ve Standartları Yasası 2006 yılında yayımlanmış, ardından 2008 yılında Hindistan Gıda Güvenliği ve Standartları Kurumu (FSSAI)'nun oluşumu ve 2011 yılında Gıda Güvenliği ve Standartları Kurallarının yürürlüğe girmesiyle gıda güvenliği konusunda ülke çapında önemli adımlar atılmıştır. Ayrıca yine Hindistan'da yapılan bir çalışmada Hindistan gida güvenliği düzenleyici sistemi FAO tarafindan önerilen beş bileşen altında incelemiştir ve iyileştirme için eylem önerisinde bulunmuştur. $\mathrm{Bu}$ beş bileşen; gıda kontrol yönetimi, gıda mevzuatı, gıda kontrol sistemleri, resmi gıda kontrol laboratuvarlar1 yapısı ve gıda güvenliği kalite bilgi eğitimi ve iletişimidir. Bu çalışmanın sonucundan elde edilen veriler doğrultusunda; Hindistan'da ulusal gıda kontrol sisteminin, dünyada değişen Sıhhi ve Bitki Sağlığı (SPS) tabanlı gıda güvenliği sistemine paralel olarak hala gelişmekte olduğu görülmüsstür. Gıda güvenliği konusunda Hindistan gibi büyük ülkelerde tek başına merkezi hükümetin görev alması işlerin daha zor ve karmaşık hale gelmesine yol açmaktadır. Dolayısıyla burada yerel yönetimlere de bazı konularda yetki devri yapılarak hem daha etkin bir denetim mekanizması geliştirilmiş olacak hem de iş yükü paylaşılarak merkezi hükümetin bu konuda yaşadığı sıkıntılar da hafifletilmiş olacaktır (Shukla vd., 2018:122,130).

\subsection{Güney Kıbrıs}

Günümüz medya organlarının daha fazla olayların üstüne gitmesi ve sosyal medyanın insanlar arasında daha fazla yaygınlaşması Güney Kıbrıs’taki gıda korkusunun çoğalmasına neden olmaktadır. İnsanlar, güvenli gida üretiminin önemini giderek daha fazla fark etmekte ve bu yüzden tüketici haklarını talep etmektedirler. Ayrıca genç nesil arasında gıda güvenliği temel bilgilerinde eksiklik olması ve yanlış yönlendirmeler bulunması da korku faktörünün artmasında etkili olmaktadır. Bununla birlikte yemek hazırlama ve tüketmede harcanan zamanın azalması da ülkede gıda güvenliği hassasiyetinin artmasına sebep olmuştur (Violaris vd., 2008:439).

Gıda güvenliğini düzenlemek her ülkede önemli bir görevdir. Güney Kıbrıs'ta bu görev, sağlık ve tarım otoriteleri dahil olmak üzere dört ana yetkili makam tarafından düzenlenmektedir. Yetkili merciler şu kamu kurumlarından oluşur: Kamu Sağlığı Hizmetleri, Devlet Genel Laboratuvarı (DGL), Veterinerlik Hizmetleri ve Tarım Dairesi. İlk ikisi Sağlık Bakanlığı bünyesinde, son ikisi ise Tarım Bakanlığı bünyesinde yer almaktadır. DGL dışındaki üç kamu kurumunun içinde yerleşik yerel ofisleri bulunurken, DGL'nin yalnızca risk değerlendirme sorumlulukları vardır. Bahse konu kurumlar, faaliyetlerini koordine etmek ve kapsama alanlarındaki çoğaltma veya boşlukları önlemek için çeşitli şekillerde uğraş vermektedirler (Hadjigeorgiou vd., 2014:91). Ayrıca, Güney Kıbrıs'ta bir ulusal gıda güvenliği otoritesinin kurulması konusundaki tutum ve inançların belirlenmesi için yapılan topluma dayalı anket çalışmasından elde edilen bulgulara gore; Güney Kıbrıs'ta, gıda güvenliği sisteminin iyileştirilmesi için tek başına bir gıda güvenliği otoritesi kurulmasının büyük fayda sağlayacağı görüşü hakimdir. Ayrıca yine çalışmanın sonucuna bakıldığında; Ulusal Gıda Güvenliği Sistemleri (UGGS)'ni reform etme konusunda Avrupa Birliği ülkelerindeki örnekleri takip etmenin de işin ciddiye alındığını göstermektedir. Bununla birlikte; Avrupa Birliği'nde merkezi düzeyde ve AB ülkelerinde en az on yıl boyunca faaliyet gösteren konsolide sistemler, pratikte üretken olduğunun kanıtlanması sebebiyle Güney Kıbrıs'ta her şeyi kapsayan bir gıda güvenliği sisteminin benimsenmesi ayrıcalığını sağladığı için Güney Kıbrıs'a bazı yararlı dersler sunabileceğini göstermiştir (Hadjigeorgiou vd., 2014:94).

\subsection{Kuveyt}

Son yıllarda Kuveyt, diğer gelişmekte olan ülkeler gibi uluslararası gıda ticaretine daha fazla dahil olmaktadır ve bunun sonucunda uluslararası gıda kontrol sistemindeki trendlerle başa çıkmak için ülkedeki gıda güvenliği konusunda yeni düzenleyici uygulamalar getirmektedir. Özellikle son yıllarda, Kuveyt gida kontrol sistemini güçlendirme çabalarını arttırdı. Örneğin, Kuveyt Belediyesi, 2009 yılının sonlarında Bakanlar Emri tarafından çıkarılacak yeni bir gıda düzenlemesi hazırladı. Ayrıca, Kuveyt Belediyesi, belediye sınırları içerisinde tüketilen gıdaların analizlerini yapmak için yeni bir merkezi gıda kontrol laboratuvarı kurmuştur. Kuveyt ayrıca ulusal gıda standardını gözden geçirmiş ve güncellemiş ve sonuç olarak Körfez ülkeleri standartlarına uygun hale getirmiştir. Fakat ilerleme kaydedilmesine rağmen, bazı zayıflıkların bulunduğu gerçektir ve halk tarafindan tüketilen gıdaların güvenliğini ve kalitesini sağlayabilen etkin gıda kontrol altyapıları geliştirmek için ilave çabalar gerekli olduğu aşikardır (Alomirah vd., 2010:496).

Kuveyt, her biri Kuveyt Belediyesi (KB) Gıda Kontrol/Denetim Bölge Ofisi'ne sahip altı eyaletten oluşmaktadır. Ayrıca, beş bölgesel KB kesim evi ve beş bölgesel KB gıda ithalat ofisi bulunmaktadır. Sağlık Bakanlığı Gıda Laboratuarı (SBGL) tek bir alana sahiptir ve gıda analizi alanındaki tüm KB faaliyetlerinin 
teknik kolu olarak görev yapmaktadır. 16 bölgesel KB ofisinin tümü, gıda denetim yasalarını uygulayan tüm KB rutin gıda denetim faaliyetleri için başka bir teknik kol olarak görev yapan gıda denetmenleriyle desteklenmektedir. Bunun yanında sağlık yüksek okulları Kuveyt gıda endüstrisi için teknik emek ve destek sağlamaktadır. İşlevsel rollerinin iyileştirilmesine yardımcı olmak amacıyla stratejik konularda KB, sağlı bakanlığı (SB) ve uygulamalı eğitim ve öğretim için kamu otoritesi (UEÖKO) bilimsel araştırmalar yapmaktadır. Kuveyt'te, başlıca araştırma faaliyetleri, gıda sektörüne araştırma ve teknik destek sağlayan Kuveyt Bilimsel Araştırma Enstitüsü (KBAE), Kuveyt Üniversitesi (KÜ) ve UEÖKÖ gibi kamu kurumları tarafından yürütülmektedir. Kuveyt gıda güvenliği ve 56 kontrol sistemi (KFSCS), Kuveyt'in gıda arzını yüksek kaliteli ve güvenli standartlarla korumayı amaçlamaktadır (Al-Mazeedi vd., 2012:55-56).

Kuveyt, 1981 yılında altı komşu üye ülke arasında birliği sağlamak için koordinasyon, entegrasyon ve ara bağlantı kurmak amaciyla kurulan bir örgüt olan Körfez İşbirliği Konseyi'nin (KİK) üyesidir. Üye ülkeler: Bahreyn, Kuveyt, Umman, Katar, Suudi Arabistan ve Birleşik Arap Emirlikleri’dir. KİK ülkelerinin karşılaştı̆̆ 1 ana zorluklardan biri, güvenli ve besleyici gıdaların yeterli bir şekilde tedarik edilmesinde sıkıntı yaşama durumudur. Sınırlı tarımsal üretim ve bölgedeki gıda talebindeki hızlı büyüme nedeniyle, bu ülkelerin ithal gıdalara olan yoğun bağımlılığı, özellikle ihracatçı ülkelerdeki bazı gıda tehditlerini takiben, gıda güvenliği ve kalitesi konusunda büyük endişe uyandırmaktadır (Örn: Et ve kümes hayvanlarında kuş gribi, deli dana ve dioksin). Bu tür gıda tehditleri nedeniyle ve bölgedeki gıda güvenliği sistemleri üzerinde daha iyi bir kontrol sağlamak için, yalnızca Kuveyt'te değil, aynı zamanda gıda politikalarının, düzenlemelerin ve standartların uyumlaştırılmasının uygulandığı KİK üyesi ülkelerde de bölgesel düzeyde büyük girişimler başlatılmıştır. Avrupa Birliği ülkelerinde olduğu gibi KİK ülkelerinin de kendi aralarında geliştirecekleri sistemler bu coğrafyada yaşayan insanların güvenilir gıdaya ulaşmasında büyük fayda sağlayacaktır. Ortak bir sistem ve ortak stratejik planlar ile denetim mekanizmalarının işleyebilirliği de daha kolay hale getirilmiş olacaktır (Alomirah vd., 2010:496,497).

\subsection{Suudi Arabistan}

Suudi Arabistan'da, daha önceleri gıda ile ilgili tüm meselelerin sorumluluğu bir dizi devlet bakanlığı ve devlet dairelerine yayılmıs durumdaydı. Gıda kontrol görevlileri, bu çok kurumlu gıda kontrol sisteminin, birtakım zayıflıklar ve sınırlamalar ile sonuçlandığını bildirmişlerdi. Bunlar: Faaliyetlerin üst üste binmesi ve gereğinden fazla çoğaltılması; ilgili tüm kurumlar arasında şeffaflık ve serbest bilgi akışı eksikliği; çeşitli kaynaklar arasındaki deneyimlerdeki farklılıklar; her kurum tarafından yönetmelik ve standartların uygulanmasında bir tutarsızlık ve halk sağlığını korumak için sorumlulukları yerine getirme konusunda yapılması gerekenleri yerine getirmek için öncelikleri belirleme konusunda çatışmalar, şeklinde sıralanabilir. Tek bir kurumda gıda kontrolüne yönelik sorumlulukların merkezileştirilmesinin ardında yatan fikir ise 1989'da, aynı zamanda Başbakan Yardımcısı, Savunma ve Havacılık Bakanı ve Genel Müfettiş, İdari Örgüt için Bakanlar Komitesi Başkanı olan Kraliyet Majesteleri Prens Sultan bin Abdül Aziz'in, gıda ve uyuşturucu için bir kamu otoritesi oluşturmak üzere hükümet sektörlerinin bir bölümünü yeniden yapılandırmayı önermesi ile gündeme gelmiştir. Fikir, tüm gıda ve uyuşturucu meseleleriyle ilgilenmek için bağımsız bir otorite oluşturma ihtiyacını ortaya çıkarmak için, yönetimsel gelişim genel sekreterliği içinden ve diğer ilgili organlardan uzmanlar ve danışmanlar dahil olmak üzere, komite grupları ve ekipleri tarafından uzun yıllar süren kapsamlı bir çalışma almıştır. Suudi Gıda ve İlaç Kurumu (SGIK) Mart 2003'te kurulmuştur. Bakanlar Kurulu, Mart 2003'te yürürlüğe giren bu yetkinin kurulmasına yönelik yasa çıkarmıştır (Al-Kandari ve Jukes, 2012:36,37).

Suudi Arabistan'da, Suudi halkının büyük bir kısmının dışarıda yemek yediği belirtilmektedir ve ülkenin Sağlık Bakanlığı'ndan gelen bilgiler, son on yılda gıda kaynaklı hastalıkların çoğaldığını bildirmektedir. 2010 yılında yaklaşı 1647 gıda kaynaklı hastalık bildirilmiş ve bu rakam ticari kaynaklardan gıda tüketimi sonucu hastalananların yaklaşık yüzde 62'sini (1029) oluşturmaktadır. Başka bir raporda, yalnızca 2011'de, 2066 kişide hastalığa neden olan 255 gıda kaynaklı hastalık vakası bildirilmiştir. Bu durum Suudi Arabistan'da gıda zehirlenmesi olaylarında sayının giderek arttığını göstermektedir. Gıda üreticilerinden kaynaklı gıda zehirlenmelerinde üç temel faktör rol oynamaktadır: Bilgi, tutum ve uygulama (Al-Shabib vd., 2016:212).

Yiyecek kontrolü ile ilaç kontrolünü bir araya getirerek aynı otorite altında, bu otoritenin bilimsel bir bilgi ve tavsiye kaynağ 1 olarak hareket etmesi, tüketicinin güvenliğini sağlamak için yüksek standartlar koymay1 sağlayacaktır. Bilim, gıda ve ilacı güvenli hale getirmek için etkili bir şekilde kullanıldığı zaman bu durum bir ülkede halk sağlığının korunmasını sağlayacak ve bu konudaki çalışmaların ilerlemesine katkıda bulunacaktır. SGIK'nda gıda sektörü ilaç sektöründen ayrı olarak faaliyet göstermektedir ve her sektörün kendi departmanları ve personeli bulunmaktadır. SGIKK gıda sektöründe; gıda yasaları ve yönetmelikleri, gıda kontrol yönetimi, gıda 
kaynaklı hastalık gözetimi ve inceleme sistemleri, denetim hizmetleri, geri çağırma ve izleme sistemleri, gıda izleme laboratuvarları ve bilgi ve tüketiciler için eğitim faaliyetlerini bir araya getirmektedir. Gıda kontrol görevlilerine göre, SGIK içindeki gıda güvenliği faaliyetlerinin merkezileştirilmesinin nedenleri; esasen Suudi Arabistan'da faaliyetlerin üst üste binmesi ve bu yüzden çok fazla çaba sarfetme gerekliliklerinin çoğalmasını azaltmak ve gıdadan sorumlu çok sayıda kamu kurumu arasındaki koordinasyonu artırarak Krallık'taki gıda güvenliği sisteminin etkinliğini arttırmaktır. Gıda kontrol sorumluluğunun merkezileştirilmesi; uygulamanın standardizasyonu, karar alma süreçlerinin birleştirilmesi ve en çok ihtiyaç duyulan ve acil durumlarda kaynakların belirlenmesi ve dağıtılması gibi gıda yasalarının ve düzenlemelerinin uyumlaştırılmasını kolaylaştırmıştır. SGİK'nu kurmanın temel amaçları arasında, Suudi Arabistan'da sağlığın korunmasına ve ilerlemesine katkıda bulunan gıda kontrolüne uygun bir düzenleyici sistem geliştirip uygulayarak, gıda zincirinde (yerel ve ithal) gıda güvenliğini sağlamak olmuştur (Al-Kandari ve Jukes, 2012:37).

\subsection{Umman}

Gıda güvenliği yönetim sistemleri; sofradan çatala güvenli gıda prensibinin sürekliliğinin benimsenmesi, tüketicinin refahının korunması ve bölgesel ve uluslararası ticareti kolaylaştırması sebebiyle büyük önem taşımaktadır. Umman Hükümeti'nin; en önemli gıda güvenliği yönetim sistemlerinden birisi olan HACCP sistemlerinin uygulanmasında ve gıda güvenliği kontrollerinin iyileştirilmesinde ilerleme kaydettiği belirtilmiştir (Al-Busaidi vd., 2017:901).

Umman'da mevcut gida güvenliği kanunu ve yönetmeliklerinin uygulanması, çeşitli devlet otoriteleri arasında üst üste binen sorumluluklarla paylaşılmakta ve çok kurumlu bir sistem olarak kabul edilmektedir. Bileşenler şunları içerir: Bölgesel Belediyeler ve Su Kaynakları Bakanlığı (BBSKB), Tarım ve Balıkçılık Varlığı Bakanlığı (TBVB), Ticaret ve Sanayi Bakanlığı (TSB), Sağlık Bakanlığ (SB), Tüketicinin Korunması İçin Kamu Kurumu (TKKK), Yerel Belediyeler (Muscat, Sohar ve Dhofar) ve Kraliyet Umman Polisi (KUP). Bu makamlar, gida kontrolünün sağlanması hususunda çeşitli görev ve sorumlulukları yerine getirir. Umman'da gıda güvenliğinin birincil otoritesi, Gıda Güvenliği Komitesi'ne (GGK) başkanlık eden Bölgesel Belediyeler ve Su Kaynakları Bakanlığı'dır. Bu komite, Gıda Güvenliği Kanununun 13. Maddesi (84/2008) ile yasal olarak kurulmuş ancak daha önceki bir Bakanlık Kararını (BK) (45/2003) değiştiren Bakanlık Kararı (BK) (272/2009) tarafından ilan edilmiştir. GGK, gıda güvenliği kontrol sisteminden sorumlu çeşitli bakanlıklar ve belediyelerden yetkilileri içermektedir (Al-Busaidi ve Jukes, 2015:57).

GGK'nin görevleri arasında, ithalat ve üretim sırasındaki gıda bütünlüğünü düzenleyen mevzuat, standartlar, şartnameler ve politikaların belirlenmesi yer almaktadır. Ek olarak, iç pazarlar, gıda depoları, hazır yemek hizmetleri, mezbahalar ve gıda kuruluşları için yeterli izleme ve denetim programlarının sürdürülmesi şarttır. Gıda hijyeni ve sanitasyon şartlarının uygulanması, esas olarak, farklı valiliklerdeki belediye makamlarının yetkisi altındadır. Gıda ithalat ve ihracatının kontrolü, farklı bakanlıklarda gıda otoritelerinin gümrük, karantina ve laboratuvarlarında yatmaktadır. Ayrıca, bu faaliyetlerin bazıları birden fazla otorite içerisinde paylaşılmaktadır. Uluslararası gıda güvenliği kontrolünün sorumluluğu farklı makamlar arasında paylaşıldığında, kaynakların verimli kullanımı ile etkili bir sistemin uygulanmasının karmaşıklaştığı belirtilmiştir. Bu durum saydamlık eksikliğine neden olabilir ve farklı yetkililer arasında serbest bilgi akışını önleyebilir. Gıda kontrol sistemleri, dünya çapında gıda işleme teknolojilerindeki değişiklikler, uluslararası gıda ticaretinin hızlı gelişimi ve gıda dağıtım sistemlerindeki ilerlemeler nedeniyle giderek daha karmaşık hale gelmektedir. Ek olarak, Umman'da olduğu gibi gıda ithalatına bağımlılık olduğunda, farklı gıda otoriteleri arasında kaynakların sınırlı olması ve yetersiz koordinasyon sağlanması, tüketicinin korunmasını ve halk sağlığının istenilen düzeyde olmasını sağlayabilen etkin bir gıda güvenliği kontrol sistemi modernize etme ve yaratma ihtiyacı doğurmaktadır (Al-Busaidi ve Jukes, 2015:57,58).

\section{MERKEZI VE YEREL YÖNETIMLER AÇISINDAN GIDA GÜVENLİĞİNIN SAĞLANMASI VE TÜRKIYE}

Türkiye'de cumhuriyet tarihine bakıldığında; gıda güvenliği konusunda yasal olarak ilk uygulamaların 1930 yılında çıkarılmış olan "1580 Sayılı Belediye Yasası” ile başladığı görülmektedir. 1930 yılı içerisinde çıkarılmış bir başka yasal uygulama olan "1593 Sayılı Umumi Hıfzıssıhha Kanunu” ile birlikte gıda güvenliği konusunda dikkat edilmesi gereken hususlar daha ayrıntılı bir şekilde ifade edilmiştir. Daha sonra; Umumi Hıfzıssıhha Kanunu'na dayanılarak gıda güvenliği konusundaki uygulamaların daha hassas ve düzenli bir şekilde uygulanabilmesi için; 1942 yılında "Gıda Nizamnamesi" ve 1952 y1lında da "Glda Maddeleri Tüzüğü" 
çıkarılmıştır. 1995 yılına gelindiğinde ise, 560 sayılı "Gıdaların Üretimi, Tüketimi ve Denetlenmesine Dair Kanun Hükmünde Kararname (KHK)" yayımlanana kadar ülke genelinde gıda mevzuatı ile ilgili bütün yasal düzenlemeler Gida Maddeleri Tüzüğü ve ilgili birkaç yönetmelikten ibaretti. Çok önemli yasal bir düzenleme olan olan 560 sayılı KHK ile birlikte, gıda hizmetleri hususunda temel ve yapısal değişiklikler getirilmiştir. Türkiye genelinde gıda üretimi yapan işletmelere ruhsat verme yetkisi ve gıda konusunda bütün denetim hizmetleri Sağlık Bakanlığı'na bırakılmıştır (Çopuroğlu vd., 2015:24).

Türkiye'nin Avrupa'nın etkisi ile gıda güvenliği konusunda göstermiş olduğu faaliyetler ilk olarak 1963 yılında Avrupa Ekonomik Topluluğu ile ortaklık anlaşması imzalamasıyla başlamıştır. Anlaşmanın imzalanmasından 24 yıl sonra (1987 yılında) Türkiye'nin AB tam üyeliğe başvurması ve bu kapsamda "Geçiş Dönemi"ne girmesi ile faaliyetler dizisi devam etmiştir. Son olarak 1999 yılında Türkiye'nin Avrupa Birliği’ne adaylığının resmen onaylanması ile bu konuda bir dönüm noktası yaşanmıştır. Avrupa Birliği'ne uyum süreci içerisinde, 2004 yılında yürürlüğe giren 5179 sayılı "Gldaların Üretimi, Tüketimi ve Denetlenmesine Dair Kanun Hükmünde Kararnamenin Değiştirilerek Kabulü Hakkında Kanun" ile gıda güvenliğinde AB mevzuatına uyum sağlayacak yeni bir dönemin başlaması sağlanmıştır. Bu uyum süreci içinde Avrupa Birliği'ne katılım hususunda açılan müzakere fasıllarından 12.si olan "Gıda Güvenliği, Veterinerlik ve Bitki Sağglı̆̆ı" faslının amacı; tarladan çatala kadar olan bütün süreçlerde gıda güvenliğinin teminini öngören kapsamlı bir mevzuat oluşturulmasıdır. 2004 yılında yürürlüğe girmiş olan 5179 sayılı Kanun, temelinde Avrupa Birliği Gıda Mevzuatı göre hazırlanmış olsa da 12. faslın açılması için gerekli altı açılış kriterinden birisi olan "Glda, Yem ve Veterinerlik Çerçeve Mevzuatı" kriteri için yeterli olamamıştır. İşte bu yüzden faslın açılmasını sağlamak amacıyla 2010 yılında gıda güvenliği konusunda AB mevzuatına uyumlu bir Kanun olan 5996 sayılı "Veteriner Hizmetleri, Bitki Sağllğgl, Glda ve Yem Kanunu" hazırlanmış ve kabul edilmiştir. Bu kanun doğrultusunda; gıda ve yem güvenilirliği, halk sağlığı, bitki ve hayvan sağlığı ile hayvan ıslahı ve refahı, tüketici menfaatleri ile çevrenin korunması alanlarında çeşitli düzenlemeler getirilmiştir. 5996 sayılı Kanun ile ülke genelinde gıdaların denetimine ilişkin konularda tek yetki Gıda, Tarım ve Hayvancılık Bakanlığı'na (yeni adı ile Tarım ve Orman Bakanlığı) verilmiştir (Çopuroğlu vd., 2015:24).

1 sayılı Cumhurbaşkanlığı kararnamesine göre Tarım ve Orman Bakanlığı içerisinde kurulan "Gıda ve Kontrol Genel Müdürlüğü", "Bitkisel Üretim Genel Müdürlüğü", "Hayvancılık Genel Müdürlüğ̈̈", "Balıkç1lı ve Su Ürünleri Genel Müdürlüğü", "Tarım Reformu Genel Müdürlügü", "Tarımsal Araştırmalar ve Politikalar Genel Müdürlüğü", "Su Yönetimi Genel Müdürlügü̈" ve "Şeker Dairesi Başkanlığı" gibi birimler doğrudan gida denetimi ile ilgili süreçlerde görev almaktadırlar. Ayrıca yine 1 sayılı kararname ile doğrudan cumhurbaşkanına bağlı "Sağllk ve Gıda Politikaları Kurulu" tesis edilmiştir. İlgili kurul (md.29/1-a), "...glda sağlı̆̆ı ve güvenliği konusunda araştırmalar yapmak, risk analizi yaparak gıda să̆lı̆̆ının korunması için politika önerileri geliştirmek", konusunda yetkilendirilmiştir.

Merkezi idare doğrudan gıda kontrolü ve denetimleri yapmasının yanı sıra gıda politikalarını daha etkin bir şekilde hayata geçirmek ve vatandaşlar için gıda güvencesi oluşturmak amacıyla bazı gıda teşekkülleri de kurmuştur. Tarım ve Orman Bakanlığına bağlı "Atatürk Orman Çiftliği Müdürlüğü" ile yine bakanlıkla ilgili "Çay İşletmeleri Genel Müdürlügüü, "Et ve Süt Kurumu Genel Müdürlüğü", "Tarım İşletmeleri Genel Müdürlüğü" ve "Toprak Mahsülleri Ofisi Genel Müdürlüğü" gibi kurumlar bu alanda faaliyette bulunmaktadırlar. Yine merkezi idarenin vesayet denetimi altında bulunan üniversiteler içerisinde de üretim ve araştırma çiftlikleri, merkezler, laboratuvarlar, hayvan hastaneleri, vd. birimler gıda güvencesi ve güvenliğine doğrudan ve dolaylı olarak katkılar sunmaktadırlar.

Türkiye'de yerel yönetimler açısından da gıda güvenliği konusunda çeşitli uygulamalar mevcuttur. Özellikle belediyeler, kendi olanakları ölçüsünde kendi mücavir alanı sınırları içerisinde tüketime sunulan gıdaların güvenliğini sağlamak için birtakım tedbirler almaktadır. Bu işletmelerin faaliyetlerini gerçekleştirebilmeleri için ihtiyaç duydukları işyeri açma ruhsatları yerel yönetimler (belediyeler, il özel idareleri) tarafindan verilmektedir. Dolayısıyla bu ruhsatların alınabilmesi için hukuken olması gereken tüm şartların yerine getirilip getirilmediği yerel yönetimler tarafindan değerlendirilmektedir. Ruhsat verilmesinden sonra da ilgili şartların muhafaza edilip edilmediği yine yerel yönetimler tarafindan denetlenerek kontrol edilmektedir.

Belediyeler kendi sorumluluk alanı içerisinde satılan gıda ürünlerinin denetimlerini görevlendirdiği zabıtalar aracılığı ile sağlamaktadır. Uygunsuz şartta ve nitelikte ürün üretimi, dağıtımı ve satışı yapan işletmelere idari yaptırımlar uygulanmaktadır. Bu denetimler gıda standartlarına uygun ürünlerin tüketiciye ulaşmasına katkı sağlamaktadır. Bu uygulamalar aynı zamanda haksız rekabetin de önüne geçmektedir. Çünkü alınması zorunlu tedbirlerin gerçekleştirilmemesi ve bazı standartların uygulanmaması bu konuda katlanılan maliyetleri ortadan kaldırarak, uygulayan işletmelere göre rekabet üstünlüğüne neden olmaktadır. Yine bu doğrultuda meyve-sebze halleri ile balık hallerinin kurulması da sağlıklı ve güvenilir ürünlerin fiyat kontrolünün yapılabilmesine olanak 
sağlamaktadır. Halk sağlığını mümkün olan en üst düzeyde korumayı hedefleyen belediyeler sadece denetim ile değil bizzat kendisi de iştiraklari aracılığıyla satışlar yapabilemektedir. Örneğin bazı il ve ilçe belediyelerinin kendi bünyelerinde "Halk Ekmek" gibi firın ürünleri üreten tesisleri kurmaları ya da "mezbaha" ya da "kesimhane" kurup işletmeleri de halk sağlığının göz önünde bulundurularak vatandaşlara uygun fiyatla ve güvenilir gıdaların sunulmasına katkı sağlamaktadır (Atik ve Atik, 2018:1515).

Türkiye'de gıda güvenliği politikalarının oluşturulması ve hayata geçirilmesinde merkezi idare, yerel idareler (il özel idaresi, belediyeler), organize sanayi bölgesi müdürlükleri, üniversiteler, üretim birlikleri, tüketici temsilcileri, özel sektör işletmeleri, gönüllü kuruluşlar, vd. paydaşlar birlikte sürece katkı sağlamaktadırlar. Ancak gıda güvenliği ve denetimi konusunda genel yetki merkezi idare (devlet) tarafindan kullanılmaktadır. Merkezi idare bu yetkisini "Sağlık Bakanlığı" ile "Tarım ve Orman Bakanlığı" gibi üst düzey kurumsal yapılar ile bu yapılara bağlı ya da ilgili veya ilişkili birimler üzerinden gerçekleştirmektedir. Yerel düzeyde ise gıda işletmelerinin açılması için ihtiyaç duyulan ruhsatname yerel yönetimler tarafindan verilmektedir. Yerel yönetimler ruhsat sonrasında da ilgili şartların taşınmaya devam edip etmediğini denetleyerek kontrol etme yetkisine sahiptir. Gıda işletmeleri birden fazla kurum ve idare tarafindan aynı anda denetlenmektedir. $\mathrm{Bu}$ durum denetim konusunda yetki dağınıklığına neden olmaktadır. bakanlıklar, kurumlar ve idareler arasında farklı konularda dağınık bir şekilde bulunan kontrol ve denetim yetkisinin tek bir kurum ya da idarede toplanması denetim konusunda daha akılcı bir planlama yapılabilmesine olanak sağlayacaktır.

\section{SONUC}

İnsanoğlunun yaşamını devam ettirmesi için günlük olarak belirli miktarda gıda ürünü tüketmesi şarttır. Fakat tüketilen bu ürünlerin sağl1kl1, güvenilir, yeterli ve sürdürülebilir olması son derece önemlidir. Ürün kalitesinin insan sağlığına uygun bir düzeyde üretim, dağıtım ve tüketimi için bir takım asgari ilke, standart, usul, norm (kural), vb. uygulamalara ihtiyaç vardır. Bu bağlamda uluslararası kuruluşlar tarafından bazı temel ilke ve standartlar hayata geçirilmiş, ihtiyaca göre de zamanla yenilenmektedir. Dünya ülkeleri de bu standartlara göre kendi gıda politikalarını hayata geçirmekte, ihtiyaç duyulan hukuk kurallarını ihdas etmekte, bu kuralları uygulayacak kurumlarını teşekkül ettirmekte, kuralların uygulanmasını denetleyerek kontrol edecek mekanizmalar kurmakta, halkın bilinç düzeyini arttıracak önleyici ve koruyucu programlar uygulamakta, kamuoyu oluşturmakta ve diğer paydaşlar ile işbirlikleri içerisinde bulunmaktadırlar.

Artan nüfus ile genel olarak tüm kentlerde, özel de ise yüksek nüfus yoğunluğuna sahip kentlerde sağlıklı ve güvenilir gıdaya ulaşma konusunda sorunlar yaşanmaktadır. Genetiği değiştirilmiş gıdalar (GDO), biyokimyasal ürünler, koruyucular, elverişsiz üretim şartları, yasaklı ürün kullanımı, muhafaza şartlarının yetersizliği, düşük kaliteli ürün kullanımı, biyolojik silah yapılma, vb. gibi sorunlar daha da ön plana çıkmaktadır. Özellikle hukuk kurallarının ve özellikle de denetim yetersizliğinin olduğu yerlerde bu sorun çok daha belirgin hale gelmektedir.

Gıda sorunları sadece yaşayan halkı değil, ileri nesilleri de tehdit eden bir sorundur. Dolayısıyla bu sorunun çözümü için görevlendirilen uluslararası, ulusal ve yerel tüm aktörlerin üzerine düşen görevi yapmas1 gerekmektedir. Gıda sorunlarının giderilebilmesi, önleyici tedbirler alınması, ortaya çıkan aksaklıkların bertaraf edilmesi ancak etkin bir kontrol ve denetim mekanizmasının kurulması ile mümkün olabilir. Problemin ulusal/ülkesel boyutta, hatta küresel ölçekte olması nedeniyle genellikle bu konuda temel yetkili aktör merkezi idare olan devletlerdir. Ancak ülkeden ülkeye farklılıklar gösterse de başta yerel yönetimler olmak üzere diğer aktörlerde bu mekanizmanın bir parçası haline getirilerek tüm paydaşlar ile birlikte ortak hareket edilme amacı güdülmektedir. Örneğin Türkiye'de sıhhi ve gayrısihhi işyerlerinin açılışı için ihtiyaç duyulan işyeri açma ruhsatları yerel yönetimler tarafından verilmektedir. Yine gerekli olan şartların sağlanmaya devam edip etmediği yine yerel yönetimler tarafindan kontrol edilmekte ve de denetlenmektedir. Gida güvenliği konusunda bilinç düzeyinin arttırılması, güvenli gıda uygulaması yapılabilmesi için tüketici dernekleri, üretim birlikleri, medya organları, gönüllü kuruluşlar vd. paydaşlar ortak kamuoyu oluşturmaktadırlar.

Türkiye'de merkezi idare olan devlet yasama yetkisine sahiptir. Anayasa düzeyinde norm oluşturma, uluslararası antlaşmalar yapma, kanun ve kararname çıkarma, uygulama esasları belirleme, yönetmelik, tüzük, genelge, tebliğ ve diğer düzenleyici adsız işlemler ihdas etme gibi yetkilere sahiptir. Yerel yönetimler ise kanunla kendi tüzel kişiliğine verilen yetkiler kapsamında idari karar alma ve işlemler yapma yetkisi ile donatılmıştır. Ayrıca merkezi idare de yerel idareler de güvenli gıda ürünlerinin üretim ve dağıtımına katkı sunmak amaciyla işletmeler kurma ve programlar geliştirme konusunda yetki sahibidirler. Merkezi idare gida güvenliği ve denetimi noktasında genel yetkiye, yerel yönetimler ise özel (verme, sayılı, sinırlı) yetkiye sahiptir. 
Gıda güvencesi ve güvenliği insan hayatına verilen önem ile doğrudan orantılıdır. Bu nedenle bu konunun genel bir kamu politikası içerisinde tesis edilip uygulanması bilinç düzeyi, gelişmişlik seviyesi, maddi kriter, kurumsal deneyim, gelişmiş teknoloji, fiziki ve maddi imkanlar gibi unsurlar ile de doğru orantılı olduğu düşünülmektedir. Buradan hareketle ülkelerin gelişmişlik düzeyi ile gıda güvenliği uygulamaları arasında da bir doğru orantının olduğunu söyleyebiliriz. Çünkü gelişmiş ülkelerde gıda güvenliği konusunda daha aktif sistemler oluşturmayı başarabilmiş ve büyük oranda da bu sistemi uzun süredir başarnyla uygulayabilmişlerdir. Elbette bu genel kanının aksine uygulama örnekleri de istisnaen yaşanabilmektedir.

Gelişmekte olan veya gelişmemiş olan ülkelerde ise sistemsel eksikliklerin kurulması ve işletilmesinde eksiklikler yaşanmasının en temel nedeni ekonomik kaygıların öncelikli halde olmasıdır. İ̧̧letme maliyetlerinin azaltılarak rekabet üstünlüğünün sağlanmas1, daha çok vergi geliri elde etme isteği, bürokratik yozlaşma, rüşvet, bilinç düzeyi düşük toplum, yetersiz kamuoyu gücü, bilgi kirliliği/yetersizliği, profesyonel personel istihdamı eksikliği, teknolojik ve fiziksel yetersizlikler bu konuda ki diğer önemli unsurlardır.

Ülkemizde gıda güvenliği konusunda merkezi yönetimin ve yerel yönetimlerin uygulamalarına bakıldığında bazı eksiklikler söz konusu olsa da diğer gelişmekte olan ülkelere kıyasla göreceli olarak bazı başarıların yakalandığı söylenebilir. Özellikle mevzuatsal alt yapının uluslararası standartlara uygun hale getirilmesi bu konudaki en önemli gelişmedir. Bu dönüşümün arka planında Avrupa Birliği'ne uyum süreci kapsamında açılan fasılların önemi oldukça fazladır. Yine yaşanan sağlık sorunları, kamuoyu etkileri ve halk talepleri gibi unsurlar da yaşanan sürece katkı sağlamıştır. Yine uygulama sırasında karşılaşılan sorunlar gıda güvenliği ile ilgili olan yasalarda ve yönetmeliklerde de bazı güncellemelerin yapılmasına ihtiyaç hissettirmiştir.

Türkiye'de kamuoyunda hukuki normlar, standartlar ve oranlar konusunda zaman zaman tartışmalar yaşanmaktadır. Özellikle zararlı olan gıda maddelerinin ürün içinde izin verilen oran sınırı, gdo'lu ürünlerin satışı, vb. hususlar gündemdeki yerlerini korumaya devam etmektedir. Ancak gıda güvenliği konusunda bazı eksiklikler ve tartışmaların varlığı yanında genel anlamda tesis edilmiştir. Gıda güvenliğinin sağlanması noktasında ihtiyaç duyulan hukuk normları yürürlüktedir.

Hukuk normları konusunda genel bir eksiklik sorunu yaşanmazken, bu kuralların uygulanması konusunda ciddi sorunlar yaşanmaktadır. Denetim ve kontrollerdeki yetersizlikler, bürokratik yozlaşma ve uygulamada birlikteliğin tam olarak sağlanamaması, yetki kargaşası bu sorunun ortaya çıkmasındaki ana unsurlardır. Birden çok bakanlık, genel müdürlük, başkanlık, kurul, kurum ve idare arasında dağıtılmış bir kontrol ve denetim mekanizması denetimde etkinlik ve verimliliğin istenilen düzeyde olmamasının önündeki en temel engeldir. Yine denetim ve kontrol ile görevli uzman personel ile ilgili yetersizlikler, alt yapı eksiklikleri, teknolojikfiziksel yetersizlikler de denetim ve kontrolün optimal düzeyde olmasını engellemektedir. Ayrıca bürokratik/siyasi yolsuzluklar (kayırma, rüşvet, vs.) da uygulamada birlikteliğin sağlanmasına ve denetimlerin etkinliğini ortadan kaldırmaya neden olmaktadır.

Türkiye'de öncelikle merkezi idare içerisindeki birimler arasında sayıca azaltılmış bir yetki ve görev paylaşımının yeniden yapılması; yerel yönetimlerin bu konuda yetki düzeyinin arttırılması; denetim birimlerinin uzman personel, fiziki altyapı, teknoloji ve bütçe yönünden zenginleştirilmesi; bürokratik ve siyasal yolsuzluğun önlenmesi/azaltılması yönünde daha somut tedbirler alınması, hukuki yaptırımların arttırılması, kamuoyu denetimlerine daha çok olanak sağlanması, şeffaflığın ve hesap verilebilirliğin arttırılması; gıda güvenliği konusunda mevcut olan aktörler/paydaşlar arasındaki koordinasyon ve iletişim kanallarının güçlendirilmesi gıda güvenliği konusunda daha büyük başarılarının elde edilmesine önemli katkılar sağlayacaktır. Gıda güvenliği konusunda tüm paydaşların içinde yer aldığı etkin, sürekli, sürdürülebilir ve dönüştürülebilir stratejik politikalar ile bu konuda daha olumlu kazanımlar sağlanacaktır.

\section{KAYNAKÇA}

AL-BUSAIDI, Moza A. ve JUKES, David J. (2015), "Assessment of The Food Control Systems in The Sultanate of Oman", Food Control, S.51, ss.55-69.

AL-BUSAIDI, Moza A., JUKES, David J. ve BOSE, Shekar (2017), "Hazard Analysis and Critical Control Point (HACCP) in Seafood Processing: An Analysis of Its Application and Use in Regulation in The Sultanate Of Oman", Food Control, S.73, ss.900-915.

AL-KANDARI, Dina ve JUKES, David J. (2012), "The Food Control System in Saudi Arabia - Centralizing Food Control Activities", Food Control, S.28, ss.33-46. 
ATiK, İlker ve ATIK, Azize - Merkezi ve Yerel Yönetimlerin Gıda Güvenliğindeki Etkileri: Dünyadan ve Ülkemizden Örnekler

AL-MAZEEDI, Hani M., ABBAS, Alaa B., AL-JOUHAR, Wafaa Y., AL-MUFTY, Siham A. ve ALMENDICAR, Yousef A. (2012), "Food Safety Review (FSR) in the State of Kuwait as a part of Arab Gulf Area", Internet Journal of Food Safety, S.14, ss.54-69.

ALOMIRAH, Husam F., AL-ZENKI, Sameer F., SAWAYA, Wajeeh N., JABSHEH, Faten, HUSAIN, Adnan J., AL-MAZEEDI, Hani M., AL-KANDARI, Dina ve JUKES, David (2010), "Assessment of The Food Control System in The State of Kuwait", Food Control, S.21, ss.496-504.

AL-SHABIB, Nasser Abdulatif, MOSILHEY, Sameh Hassan ve HUSAIN, Fohad Mabood (2016), "CrossSectional Study on Food Safety Knowledge, Attitude and Practices of Male Food Handlers Employed in Restaurants of King Saud University, Saudi Arabia", Food Control, S.59, ss.212-217.

ATIK, İlker ve ATIK, Azize (2018), "Belediyelerin Gıda Güvenliğindeki Rolü", Alanya Uluslararası Yerel Yönetimler Sempozyumu Bildiriler Kitabı, Nobel Yayınları, Ankara, ss.1513-1516.

CHEN, Jun-Shi (2009), "What Can We Learn from the 2008 Melamine Crisis in China?", Biomedical And Environmental Sciences, S.22, ss.109-111.

CSFS - CENTRE FOR STUDIES IN FOOD SECURITY (2015), The Five A's of Food Security, Ryerson Üniversitesi, Toronto, http://www.ryerson.ca/foodsecurity/our-approach.html (Erişim tarihi: 15.07.2015).

ÇOPUROĞLU, Gizem, KASIMOĞLU DOĞRU, Aylin ve AYAZ, Naim Deniz (2015), "Türk Glda Mevzuatında Risk Analizi", Etlik Veteriner Mikrobiyoloji Dergisi, S.26(1), ss.23-28.

FAO (1983), World Food Security: a Reappraisal of The Concepts and Approaches, Director General's Report, Rome.

HADJIGEORGIOU, Andreas, TALIAS, Michael A., SOTERIADES, Elpidoforos S., PHILALITHIS, Anastasios, PSAROULAKI, Anna, GIKAS, Achilleas ve TSELENTIS, Yiannis (2014), "Attitudes and Beliefs on The Establishment of a National Food Safety Authority in Cyprus. A Population-Based Survey", Appetite, S.75, ss.90-96.

KETTUNEN, Karoliina, NEVAS, Mari ve LUNDÉN, Janne (2017), "Challenges in Using Administrative Enforcement Measures in Local Food Control", Food Control, S.76, ss.34-41.

KETTUNEN, Karoliina, PESONEN, Susanna, LUNDÉN, Janne ve NEVAS, Mari (2018), "Consistency and Risk-Basis of Using Administrative Enforcement Measures in Local Food Control", Food Control, S.85, ss.199-211.

KOÇ, Gökçe ve UZMAY, Ayşe (2015), "Gıda Güvencesi ve Gıda Güvenliği:Kavramsal Çerçeve, Gelişmeler ve Türkiye", Tarım Ekonomisi Dergisi, S.21(1), ss.39-48.

KOTSANOPOULOS, Konstantinos V. ve ARVANITOYANNIS, Ioannis S. (2017), "The Role of Auditing, Food Safety, and Food Quality Standards in the Food Industry: A Review", Comprehensive Reviews in Food Science and Food Safety, S.16, ss.760-775.

LÄIKKÖ-ROTO, Tiina ve NEVAS, Mari (2014), "Auditing Local Official Food Control: Perceptions of Auditors and Auditees", Food Control, S.37, ss.135-140.

LÄIKKÖ-ROTO, Tiina, MÄKELÄ Silja, LUNDÉN, Janne, HEIKKILÄ, Jaakko ve NEVAS, Mari (2015), "Consistency in Inspection Processes of Food Control Officials and Efficacy of Official Controls in Restaurants in Finland ", Food Control, S.57, ss.341-350.

LÄIKKÖ-ROTO, Tiina, LUNDÉN, Janne, HEIKKILÄ, Jaakko ve NEVAS, Mari (2016), "Prerequisites for Effective Official Food Control", Food Control, S.61, ss.172-179.

LEISNER, Jorgen J., LUND, Thomas Baker, FRANDSEN, E.A., ANDERSEN, Nana B.A., FREDSLUND, Lise, NGUYEN, Vi P.T. ve KRISTIANSEN, Thomas (2014), "What Consumers Expect from Food Control and What They Get - A Case Study of The Microbial Quality of Sushi Bars in Denmark", Food Control, S.45, ss.76-80.

LUECKL, Johannes, WEYERMAIR, Karin, MATT, Monika, MANNER, Karin ve FUCHS, Klemens (2019), "Results of Official Food Control in Austria 2010-2016", Food Control, S.99, ss.190-201.

LUNDÉN, Janne (2013), "Reasons for Using Enforcement Measures in Food Premises in Finland", Food Control, S.31, ss.84-89. 
MÄKELÄ, Johanna ve RAUTAVIRTA, Kaija (2018), "Food, Nutrition, and Health in Finland", Nutritional and Health Aspects of Food in Nordic Countries (Ed. Veslemøy Andersen, Eirin Bar, Wirtanen Gun), Elsevier, United Kingdom, ss.127-143.

RAUSCHER GABERNIG, Elke, KUCHLING, Sabrina, OEHLINGER, Richard, WOLF, Josef ve FUCHS, Klemens (2016), "Risk Ranking of Mycotoxins Based on Exposure and Toxicity for The Austrian Population", Toxicology Letters, S.258, ss.165-166.

SHUKLA, Seema, SHANKAR, Ravi ve SINGH, Surya Prakash (2014), "Food Safety Regulatory Model in India", Food Control, S.37, ss.401-413.

SHUKLA, Seema, SINGH, Surya Prakash ve SHANKAR, Ravi (2018), "Evaluating Elements of National Food Control System: Indian Context", Food Control, S.90, ss.121-130.

TGDF - TÜRK GIDA VE İÇECEK SANAYI DERNEKLERI FEDERASYONU (2011), Çiftlikten Çatala Gıda Güvenliği, TGDF Yayınları, Ankara.

TURKU, Mikko, LEPISTÖ, Outi ve LUNDÉN, Janne (2018), "Differences Between Official Inspections and Third Party Audits of Food Establishments", Food Control, S.85, ss.459-465.

VIOLARIS, Yiannis, BRIDGES, Olga ve BRIDGES, James W. (2008), "Small businesses - Big risks: Current status and future direction of HACCP in Cyprus", Food Control, S.19, ss.439-448.

YANG, Lijie, QIAN, Yongzhong, CHEN, Chen ve WANG, Fang (2012), "Assessing the Establishment of AgroFood Control Systems Based on A Relevant Officials' Survey in China", Food Control, S.26, ss.223-230.

1 sayılı Cumhurbaşkanlığı Teşkilatı Hakkında Cumhurbaşkanlığı Kararnamesi (10.07.2018 tarih ve 30474 sayil1 Resmi Gazete). 